\title{
The influence of SCR-DPF system on the exhaust emissions of inland waterway vessels
}

JEL: Q01 DOI: 10.24136/atest.2019.044

Data zgłoszenia: 15.12.2018 Data akceptacji: 08.02.2019

Słowa kluczowe: SCR-DPF system, exhaust emission, inland waterway vessel.

\section{Introduction}

Many years of research on vessel operations, carried out since vessels powered by alternative fuels were first allowed, have estimated the values of reduction in emission of harmful substances into the atmosphere. It has been established that vessels may reduce their emission of carbon dioxide by $20-25 \%$, nitrogen oxides by $85-90 \%$ and sulphur compounds and solid particles by almost $100 \%$ as compared to other fuelling systems, which is compliant with the ECAs (Emission Control Areas) requirements, binding in the Baltic Sea Region and in the North Sea Region since 2015. In recent years multiple scientific and research institutions have carried out studies concerning the evaluation of the results of introducing limitations on the emission of harmful substances into the atmosphere, emitted by engines fuelled with conventional fuels, concerning their industrial, economic, environmental and safety and health protection aspects. On the 19 September 2016 the European Parliament and the Council have adopted Regulation (EU) 2016/1628 on requirements relating to gaseous and particulate pollutant emission limits and type-approval for internal combustion engines for non-road mobile machinery, amending Regulations (EU) No $1024 / 2012$ and (EU) No 167/2013, and amending and repealing Directive 97/68/EC. This document lays down harmonised rules for the EU type-approval of engines for non-road mobile machinery and sets out new stricter emission limits for newly built inland waterway vessels (Stage V). This is the first of a series articles describing the problems of using SCR-DPF systems on an inland vessels.

The aim of the research is to point to technology thanks to which the currently used vessels with traditional engines would be able to comply with those strict norms set out for international waterways.

\section{Emission norms for inland waterway vessel engines powered by conventional fuels}

The amendment of the act on the prevention of pollution by ships has been binding since 1 January 2015. This statute also concerns inland waterway vessels, involving particularly those sailing areas which include sea waters. The amendment implements Directive 2012/33/EU of the European Parliament and of the Council of 21 November 2012. This act enables Poland to comply with the more rigorous international requirements concerning the sulphur content of marine fuels used by vessels operating in EU waters. It is another legal act which obliges all waterway users to comply with environmental standards.
The binding Regulation 2016/1628 is part of European policy of sustainable transport development and reducing the emission of harmful substances into the atmosphere. The regulation covers two categories of engines:

I. IWP - engines exclusively for use in inland waterway vessels, for their direct or indirect propulsion, or intended for their direct or indirect propulsion, having a reference power that is greater than or equal to $19 \mathrm{~kW}$,

II. auxiliary engines exclusively for use in inland waterway vessels and having a reference power that is greater than or equal to 19 $\mathrm{kW}$.

In the past CCNR1 and CCNR2 standards were used to prevent air pollution, and currently STAGE 5 norm is used (Table 1, 2, 3).

Tab. 1. Emission standards according to $\mathrm{NO}_{x}$ and PM amounts, developed by Central Commission for Navigation on the Rhine, in force on the EU inland waterways

\begin{tabular}{|l|l|l|l|l|}
\hline \hline No. & CCNR standard & In force [years] & $\mathrm{NO}_{\mathrm{x}}[\mathrm{g} / \mathrm{kWh}]$ & $\mathrm{PM}[\mathrm{g} / \mathrm{kWh}]$ \\
\hline 1. & CCR 0 & $<2002$ & - & - \\
\hline 2. & CCR 1 & $2002-2007$ & 9.2 & 0.54 \\
\hline 3. & CCR 2* & $2007-$ & 6.0 & 0.20 \\
\hline
\end{tabular}

$\mathrm{CCR} 2 \approx \mathrm{EU}$ Stage IIIA, NRMM

Source: Authors' own compilation based on EIBIP data.

Tab. 2. Exhaust emission standards according to emission levels per engine cylinder, developed by Central Commission for Navigation on the Rhine and the European Commission, in force on the EU inland waterways

\begin{tabular}{|c|c|c|c|c|c|}
\hline Engine catego & -Value (D) & In & $\mathrm{CO}$ & $\mathrm{HC}+\mathrm{NO}$ & PM \\
\hline ry & {$\left[\mathrm{dm}^{3}\right]$ per engine cylinder } & [years] & {$[\mathrm{g} / \mathrm{kWh}$} & {$[\mathrm{g} / \mathrm{kWh}]$} & {$[\mathrm{g} / \mathrm{kW}$} \\
\hline V1:1 & $D \leq 0.9 ; P_{N}>37 k W$ & $2007-2018$ & 5.0 & 7.5 & 0.40 \\
\hline $\mathrm{V} 1: 2$ & $0.9<D \leq 1.2$ & $2007-2018$ & 5.0 & 7.2 & 0.30 \\
\hline V1:3 & $1.2<\mathrm{D} \leq 2.5$ & $2007-2018$ & 5.0 & 7.2 & 0.20 \\
\hline V1:4 & $2.5<D \leq 5$ & $2009-2018$ & 5.0 & 7.2 & 0.20 \\
\hline V2:1 & $5<D \leq 15$ & $2009-2018$ & 5.0 & 7.8 & 0.27 \\
\hline$V 2: 2$ & $\begin{array}{l}15<D \leq 20 ; P_{N} \leq 3300 \\
k W\end{array}$ & $2009-2018$ & 5.0 & 8.7 & 0.50 \\
\hline V2:3 & $\begin{array}{l}15<D \leq 20 ; P_{N}>3300 \\
k W\end{array}$ & 2009-2018 & 5.0 & 9.8 & 0.50 \\
\hline V2:4 & $20<D \leq 25$ & 2009-2018 & 5.0 & 9.8 & 0.50 \\
\hline $\mathrm{V} 2: 5$ & $25<D \leq 30$ & $2009-2018$ & 5.0 & 11.0 & 0.50 \\
\hline
\end{tabular}

Source: Authors' own compilation based on EIBIP data.

The latest STAGE $V$ standard introduces the following restrictions on the emission levels, as compared to former limit values for the selected engine categories:

a) reducing $\mathrm{CO}$ by $81 \%$ for IWP-v/c- 5 ,

b) reducing $\mathrm{NO}_{x}$ by $80-89,1 \%$ for IWP-v/c-4,

c) reducing $\mathrm{NO}_{x}$ by $93,3-96,3 \%$ for IWP-v/c-5,

d) reducing PM by $90-95 \%$ for IWP-v/c-4,

e) reducing PM by $90-95 \%$ for IWP-v/c- 5 
Tab. 3. Exhaust emission standards according to emission levels developed by Central Commission for Navigation on the Rhine and the European Commission, in force on the EU inland waterways from 2019 (STAGE V standard)

Emission level according to STAGE $\mathrm{V}$ standard wg normy STAGE V, taking into account engine category

\begin{tabular}{|l|l|l|l|l|l|l|l|}
\hline $\begin{array}{c}\text { Engine } \\
\text { category }\end{array}$ & \multicolumn{1}{|c|}{$\mathrm{P}_{\mathrm{N}}[\mathrm{kW}]$} & $\begin{array}{r}\text { In force } \\
{[\text { years] }}\end{array}$ & $\begin{array}{c}\mathrm{CO} \\
{[\mathrm{g} / \mathrm{kWh}]}\end{array}$ & $\begin{array}{c}\mathrm{HC} \\
{[\mathrm{g} / \mathrm{kWh}]}\end{array}$ & $\begin{array}{c}\mathrm{NO}_{\mathrm{x}} \\
{[\mathrm{g} / \mathrm{kWh}]}\end{array}$ & $\begin{array}{c}\mathrm{PM} \\
{[\mathrm{g} / \mathrm{kWh}]}\end{array}$ & $\begin{array}{c}\mathrm{PN} \\
{[1 / \mathrm{kWh}]}\end{array}$ \\
\hline IWP-v/c-1 & $37 \leq \mathrm{P}_{\mathrm{N}}<75$ & from 2019 & 5.00 & 4.70 & 0.30 & - \\
\hline IWP-v/c-2 & $\begin{array}{l}75 \leq \mathrm{P}_{\mathrm{N}}< \\
130\end{array}$ & from 2019 & 5.00 & 5.40 & & 0.14 & - \\
\hline IWP-v/c-3 & $\begin{array}{l}130 \leq \mathrm{P}_{\mathrm{N}}< \\
300\end{array}$ & from 2019 & 3.50 & 1.00 & 2.10 & 0.11 & - \\
\hline IWP-v/c-4 & $\begin{array}{l}300 \leq \mathrm{P}_{\mathrm{N}}< \\
1000\end{array}$ & from 2020 & 3.50 & 0.19 & 1.20 & 0.02 & $1 \times 10^{12}$ \\
\hline IWP-v/c-5 & $\mathrm{P}_{\mathrm{N}} \geq 1000$ & from 2021 & 3.50 & 0.19 & 0.40 & 0.01 & $1 \times 10^{12}$ \\
\hline
\end{tabular}

Source: Authors' own compilation based on EIBIP data.

According to binding legal provisions, any inland waterway vessel must meet the imposed emission standards, depending on navigation region. Detailed requirements in this regard are set out also by Directive (EU) 2016/1629 of the European Parliament and of the Council of 14 September 2016 laying down technical requirements for inland waterway vessels, amending Directive 2009/100/EC and repealing Directive 2006/87/EC. Every vessel applying for a Union inland navigation certificate must meet the imposed standards. The Directive does not apply to:

a) ferries;

b) naval vessels;

c) seagoing ships, including seagoing tugs and pushers, which operate or are based on tidal waters or operate temporarily on inland waterways, provided that they carry at least:

- a certificate proving conformity with the 1974 International Convention for the Safety of Life at Sea (SOLAS), or equivalent certificate; a certificate proving conformity with the 1966 International Convention on Load Lines, or equivalent, and an international oil pollution prevention (IOPP) certificate proving conformity with the 1973/78 International Convention for the Prevention of Pollution from Ships (Marpol),

- in case of seagoing ships not covered by SOLAS the 1966 International Convention on Load Lines or Marpol, the relevant certificates and the freeboard marks required by the laws of their flag states,

- in the case of passenger vessels not covered by any of the Conventions referred to in the first indent, a certificate on safety rules and standards for passenger ships issued in conformity with Directive 2009/45/EC of the European Parliament and of the Council (8), or

- in the case of recreational craft not covered by any of the Conventions referred to in the first indent, a certificate of the country of which it carries the flag, demonstrating an adequate level of safety.

\section{A conceptual design for a SCR-DPF system in the engine of a pusher}

A conceptual design of a system of exhaust emission treatment should be - in accordance with the principles of technical design made based on a hierarchic construction design. According to those principles, the designed system should be able to work independently in a given scope.

Pursuant to those assumptions, the hierarchic construction design should comprise of:

1. Control system,

2. Equipment necessary to perform the work of the exhaust treatment system,
3. Components performing a part of main functions or auxiliary functions of the devices,

4. Components - functional parts of the system,

5. Structural elements - component parts made of one piece of material,

6. Precast units - component parts with an unfinished machining process,

7. Functional surfaces - surfaces of structural elements which cooperate with functional surfaces of other structural elements, subject to the design process (manufacturing tolerances, surface smoothness, hardness, etc.).

8. Free surfaces - other surfaces of structural elements, which are usually not subject to the design process.

According to the principles of engineering design, the structure should be optimised for given circumstances in accordance with basic optimising criteria. Detailed principles of construction include the following:

1. Functionality - fulfilling the basic functions of the machine/device,

2. Reliability and durability - obtaining the desired probability of reliability,

3. Efficiency - obtaining the assumed and economically determined technical and technological efficiency,

4. Lightness - obtaining the right weight of the machine/device,

5. Availability of materials - making individual system components from materials available on the market

6. Appropriate load transfer system - the right choice of the scheme,

7. Manufacturability - enabling the most favourable conditions for making system components,

8. Ease of use - ensuring the simplicity of maintaining the machine/equipment in technical readiness,

9. Ergonomics - adapting the structure to safety requirements,

10. Compliance with standards and regulations - use of standards and compliance with applicable regulations of e.g. the Office of Technical Inspection (Urzad Dozoru Technicznego) or Technical Inspection Commission (Techniczna Komisja Inspekcyjna) operating at inland navigation offices,

11. Others, e.g.: environmental impact, aesthetics, resistance to external conditions, etc.

Construction principles should be used in the process of technical design since the optimum concept to solve a design problem may impact its quality and competitiveness.

An important element determining the implementation of the exhaust gas cleaning system on an inland vessel is its compliance with technical, formal and legal requirements and therefore it is necessary to refer to the engine parameter protocol, especially at the pre-implementation stage, in order to determine the real limit levels of exhaust emissions.

A new engine parameter protocol means a document compliant with Annex V, which lists all the parameters, including engine modifications, its parts and settings, which may affect the level of gaseous and particulate pollutant emission. After each significant modification to the engine, an exceptional check must be performed. The results of the check, specified in Article 8a.02 paragraphs 4-6, are entered into the engine parameter protocol. These checks are performed based on engine producer's instructions concerning monitoring those engine parts which are relevant to exhaust emissions. Instructions prepared by the producer and authorised by a competent body specify those relevant parts, as well as regulations and 
parameters, based on which one may ensure uninterrupted compliance with emission limits. The instruction should contain at least:

1. Engine type and, if necessary, engine family together with rated power and rated speed;

2. A list of engine parts and parameters, relevant to exhaust emissions;

3. Engine parameters relevant to exhaust emissions, such as ranges of settings for injection, permissible coolant temperature, maximum exhaust back pressure, etc.

4. Unambiguous characteristics which allow to identify the approved parts, relevant to exhaust emissions (technical documentation and a document certifying the approval of the SCRDPF system for installation). During the installation test, pursuant to Article 9.00 (8.6) and in the case of indirect tests pursuant to Article 9.00 (8.7) and special tests, a competent body will check the current condition of the engine as regards its components, regulations and parameters specified in the instructions. If the indirect tests show that regarding their parameters, components and adjustable functions, the installed engines comply with the specifications set out in the instructions pursuant to Article 9.00 (8.14), it may be then assumed that the exhaust system for emission of gases and solid particles is also compliant with basic emission limits. If the engine installed in a vessel belongs to an engine family, then there might not be any alterations or modifications which could adversely affect the gaseous and particulate pollutant emissions or which are outside the proposed limits.

The technology to treat gaseous and particulate pollutants in inland waterway vessels has greatly developed within the past few years. A special attention should be paid to the SCR-DPF systems, DPF with an active regeneration or SCR, whose diagrams are shown in Figure 1 and short characteristics in Table 4.

The installation the SCR-DPF according to the Directive guidelines must be subject to special check and obtain an entry in the engine parameter protocol about the compliance of the scope of exhaust emission standards with homologation and technical specification.

Tab. 4. Systems limiting the gaseous and particulate pollutant emissions used in inland vessels

\begin{tabular}{|c|c|}
\hline System & Characteristics \\
\hline SCR-DPF & $\begin{array}{l}\text { The system is compact and may be installed in machinery } \\
\text { spaces of limited volume. The SCR catalyst is installed behind } \\
\text { the DPF blocks (Figure 3). The urea injection system may be } \\
\text { controlled via a CAN module or an air boost sensor. The } \\
\text { system works both with a passive and active regeneration of a } \\
\text { particulate filter. An active filter regeneration from fuel injection } \\
\text { allows the system to work regardless of the exhaust tempera- } \\
\text { ture. The system is fitted with a by-pass valve, required by } \\
\text { certification authorities, and with an HMl controller, which } \\
\text { allows to check all working parameters. The system was } \\
\text { designed in order to replace a silencer and ensures noise } \\
\text { reduction. The system allows for a PM reduction of over } 95 \% \\
\text { and } \mathrm{NO}_{x} \text { reduction of up to } 95 \% \text {. }\end{array}$ \\
\hline $\begin{array}{l}\text { DPF with an } \\
\text { active regenera- } \\
\text { tion }\end{array}$ & $\begin{array}{l}\text { The system works both with a passive and active regeneration } \\
\text { of the particulate filter. An active filter regeneration from fuel } \\
\text { injection allows the system to work even at really low exhaust } \\
\text { temperatures and to keep a low exhaust backpressure. Passive } \\
\text { regeneration happens when the exhaust temperature exceeds } \\
250^{\circ} \mathrm{C} \text { and lengthens intervals between consecutive fuel } \\
\text { injections. It allows for a PM reduction of over } 95 \% \text {. }\end{array}$ \\
\hline SCR & $\begin{array}{l}\text { It is controlled via a CAN module or an air boost sensor. It is } \\
\text { characterised by long renovation intervals and is sulphur- } \\
\text { resistant. . The system allows for a } \mathrm{NO}_{x} \text { reduction of up to } 95 \% \text {. }\end{array}$ \\
\hline
\end{tabular}

Source: Authors' own compilation based on: (ECOEXHAUST, 2018). a)

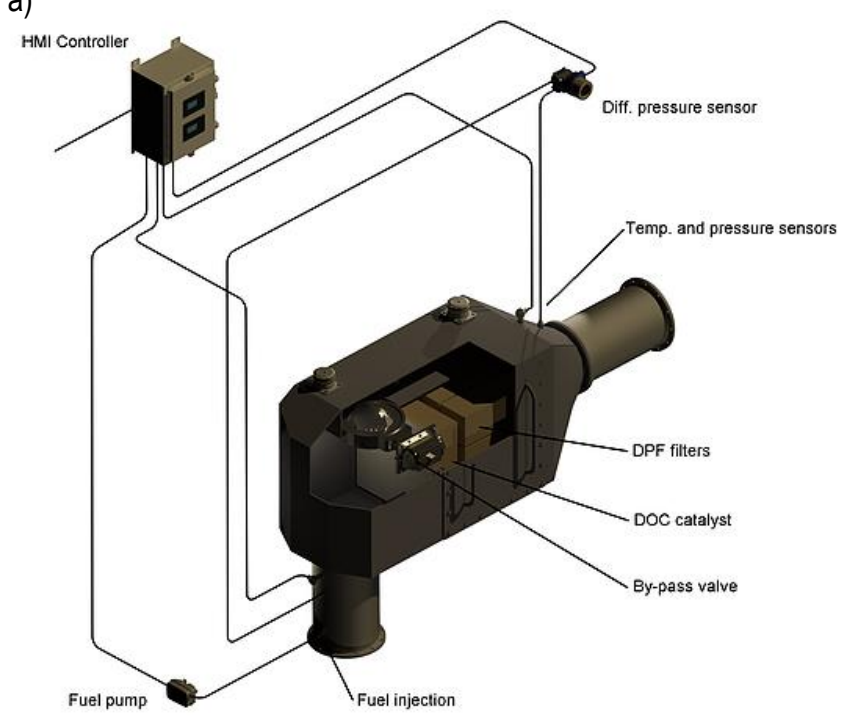

b)
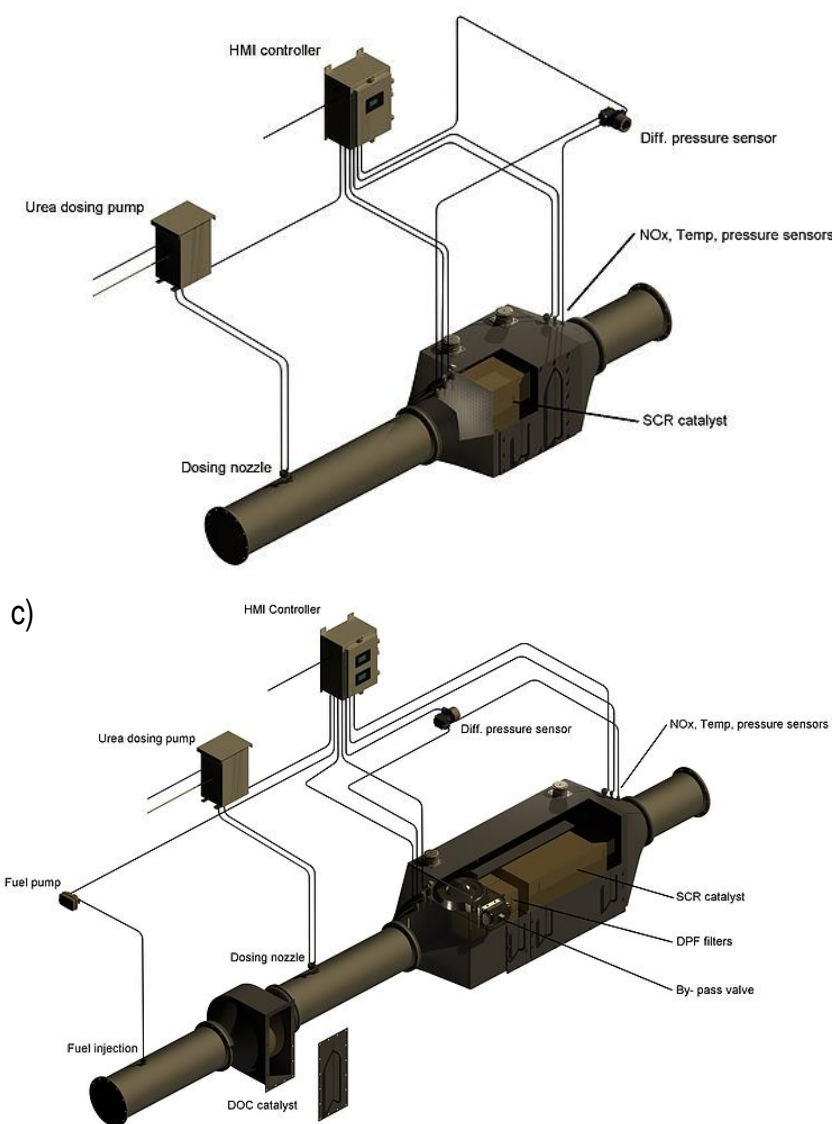

Fig. 1. Diagrams of the a) SCR-DPF, b) DPF with an active regeneration, c) SCR systems.

Source: https://www.ecoexhaust.eu/kopia-product.

\section{The results of exhaust emission tests prior to the SCR-DPF}

system implementation in the engine of a pusher

The aim of the study is to meet the STAGE V standards by implementing an exhaust gas cleaning system with SCR-DPF technology in a pusher (Table 5). This unit is designed to navigate regions $1,2,3$ and 4, excluding region $R$. In the course of the vessel's operation, the engine was replaced by another, which is not a replacement engine as defined by applicablr provisions, and the power of the engine was increased from $221 \mathrm{~kW}$ to $370 \mathrm{~kW}$. The study was conducted under the 2014-2020 Regional Operational Program for the Mazowieckie Region (RPO WM 2014-2020), 1.2. R\&D activity of 
enterprises, The use of R\&D in economy, project title: Construction and testing exhaust gas cleaning system designed for ships and yachts.

Tab. 5. Basic details of the examined inland waterway vessel

\begin{tabular}{|l|l|}
\hline \hline Vessel type & Pusher \\
\hline Shipyard & Pińska River Shipyard (Belarus) \\
\hline Home port & SZCZECIN \\
\hline Construction number & $570 \mathrm{~A} / 6$ \\
\hline Construction year & 1978 \\
\hline Height [m] & 1.60 \\
\hline Width [m] & 5.20 \\
\hline Length [m] & 24.76 \\
\hline Navigation area (draft 1m) & 2,3 \\
\hline Standard engine installed on the vessel & $\begin{array}{l}\text { Barnał ZSRR, 3D12A1 } \\
\text { Power 221 [KW] }\end{array}$ \\
\hline \multirow{3}{*}{ Engine used after the modernization of of } & $\begin{array}{l}\text { KMD S14 III-500PK } \\
\text { the drive system }\end{array}$ \\
& $\begin{array}{l}\text { Type R4* II*E2E3*0048*00 } \\
\text { Power 370 [kW] } \\
8 \text { cylinders, 1800 [1/min] }\end{array}$ \\
\hline
\end{tabular}

Source: Authors' own compilation based on register data of the vessel.

The tests were performed in real environment, on the Mescherin-Szczecin route, according to the adapted methodology. The vessel was fully technically ready and had had its engine checked. The aim of the tests was to determine the pollutant emission limits with variable system parameters.

Mean unit emission presented in the tests refers to unit emissions in standard conditions, which have been averaged according to standard test cycle, taking into account statistical weights.

The analyser used in testing had been calibrated before the test and then checked again afterwards. Calibration gases had valid certificates. After the testing was completed, a leak test of the exhaust gas intake system from the exhaust system of the engine was performed. Exhaust gas samples were collected continuously from the outlet system. The observed value of concentrations of exhaust components, which was used for calculations, constitutes a mean value from real time measurements of each final phase of the test cycle programme.

Measuring cycle included a range of engine operation from 15\% to $100 \%$ of actual engine capability; time chosen for analysis constituted a resultant of the entire cycle. Table 6 presents the load condition of the analysed vessel depending on the navigation type, and Tables 7 and 8 - results of exhaust emission measurements according to the measurement procedure.

Tab. 6. Load condition of the analysed vessel depending on the navigation type.

\begin{tabular}{|c|c|c|c|c|c|c|c|c|}
\hline \multirow{2}{*}{\multicolumn{2}{|c|}{\begin{tabular}{|l} 
Maximum \\
dimensions
\end{tabular}}} & \multicolumn{4}{|c|}{ Sailing direction and engine load } & \multicolumn{2}{|c|}{$\begin{array}{l}\text { Cross section }\left[m^{2}\right] \text { at } \\
\text { maximum draft }\end{array}$} & \multirow[t]{3}{*}{ Notes } \\
\hline & & \multicolumn{2}{|c|}{ Upstream } & \multicolumn{2}{|c|}{ Downstream } & \multirow[b]{2}{*}{ Upstream } & \multirow[b]{2}{*}{$\begin{array}{l}\text { Down- } \\
\text { stream }\end{array}$} & \\
\hline length & width & \begin{tabular}{|l|} 
Loaded \\
{$[\mathrm{t}]$}
\end{tabular} & empty & $\begin{array}{l}\text { Loaded } \\
\text { [t] }\end{array}$ & empty & & & \\
\hline 120.00 & 9.00 & 1100.00 & Yes & 1100.00 & Yes & 14.50 & 14.5 & \begin{tabular}{|l|} 
Region \\
$2,3,4$ \\
\end{tabular} \\
\hline 123.00 & 8.20 & 1400.00 & Yes & 1400.00 & Yes & 17. & 17. & $\begin{array}{l}\text { Region } \\
3,4\end{array}$ \\
\hline 125.00 & 8.25 & 1400.00 & Yes & 1400.00 & Yes & 17.80 & 17.80 & Regio \\
\hline
\end{tabular}

Source: Authors' own compilation based on register data of the vessel.
Tab. 7. Results of exhaust emission measurements after the implementation of an exhaust gas cleaning system with SCR-DPF technology on a pusher-type inland waterway vessel

\begin{tabular}{|c|c|c|c|c|c|c|}
\hline & & \multicolumn{5}{|c|}{ Engine load [\%] } \\
\hline Details & Units & 15 & 25 & 50 & 75 & 100 \\
\hline Exhaust temperature & {$\left[{ }^{\circ} \mathrm{C}\right]$} & 45.86 & 76.44 & 152.88 & 229.31 & 305.8 \\
\hline $\mathrm{CO}_{2}$ & [\%] & 1.27 & 2.11 & 4.23 & 6.34 & 8.45 \\
\hline qA b loss & [\%] & 3.10 & 5.16 & 10.33 & 15.49 & 20.7 \\
\hline Air-fuel ratio Lambda $\lambda$ & {$[-]$} & 0.43 & 0.71 & 1.42 & 2.13 & 2.84 \\
\hline $\mathrm{O}_{2}$ & [\%] & 1.48 & 2.46 & 4.92 & 7.38 & 9.8 \\
\hline $\mathrm{CO}$ & [ppm] & 204.22 & 340.37 & 680.74 & 1021.10 & 1361 \\
\hline NO [ppm] & [ppm] & 229.13 & 381.88 & 763.75 & 1145.63 & 1528 \\
\hline Thrust & [mbar] & 0.90 & 1.50 & 3.00 & 4.50 & 5.998 \\
\hline CO (undiluted) & [ppm] & 395.81 & 659.68 & 1319.36 & 1979.04 & 2639 \\
\hline Efficiency $b$ & {$[\%]$} & 11.89 & 19.82 & 39.63 & 59.45 & 79.3 \\
\hline Air temperature & {$\left[{ }^{\circ} \mathrm{C}\right]$} & 3.64 & 6.07 & 12.13 & 18.20 & 24.3 \\
\hline $\mathrm{O}_{2} \mathrm{pds}$ & [\%] & 1.48 & 2.46 & 4.92 & 7.38 & 9.8 \\
\hline Dew point $\mathrm{Td}$ & {$\left[{ }^{\circ} \mathrm{C}\right]$} & 6.22 & 10.37 & 20.74 & 31.12 & 41.5 \\
\hline
\end{tabular}

Source: Authors' own tests.

Tab. 8. Results of exhaust emission measurements after the implementation of an exhaust gas cleaning system with SCR-DPF technology on a pusher-type inland waterway vessel

\begin{tabular}{|l|l|l|l|l|}
\hline \hline & & \multicolumn{3}{|c|}{ Engine load [\%] } \\
\hline Details & Units & $\begin{array}{l}\text { Minimum } \\
\text { value }\end{array}$ & $\begin{array}{l}\text { Maximum } \\
\text { value }\end{array}$ & $\begin{array}{l}\text { Weighted } \\
\text { average }\end{array}$ \\
\hline Exhaust temperature & {$\left[{ }^{\circ} \mathrm{C}\right]$} & 104.3 & 428.1 & 305.8 \\
\hline $\mathrm{CO}_{2}$ & {$[\%]$} & 2.35 & 11.43 & 8.45 \\
\hline $\mathrm{qA}$ b loss & {$[\%]$} & 14.9 & 32.7 & 20.7 \\
\hline Air-fuel ratio Lambda $\mathrm{A}$ & {$[-]$} & 1.39 & 6.77 & 2.84 \\
\hline $\mathrm{O}_{2}$ & {$[\%]$} & 5.9 & 17.9 & 9.8 \\
\hline $\mathrm{CO}$ & {$[\mathrm{ppm}]$} & 429 & 2461 & 1361 \\
\hline $\mathrm{NO}$ [ppm] & {$[\mathrm{ppm}]$} & 439 & 2031 & 1528 \\
\hline Thrust & {$[\mathrm{mbar}]$} & 5.337 & 23.718 & 5.998 \\
\hline Undiluted CO & {$[\mathrm{ppm}]$} & 1721 & 3599 & 2639 \\
\hline Efficiency b & {$[\%]$} & 67.3 & 85.1 & 79.3 \\
\hline Air temperature & {$\left[{ }^{\circ} \mathrm{C}\right]$} & 22.0 & 30.8 & 24.3 \\
\hline O 2 pds & {$[\%]$} & 5.9 & 17.9 & 9.8 \\
\hline Dew point Td & {$\left[{ }^{\circ} \mathrm{C}\right]$} & 28.5 & 47.6 & 41.5 \\
\hline Source: AuthOrs $\mathrm{OWn}$ & & &
\end{tabular}

Source: Authors' own tests.

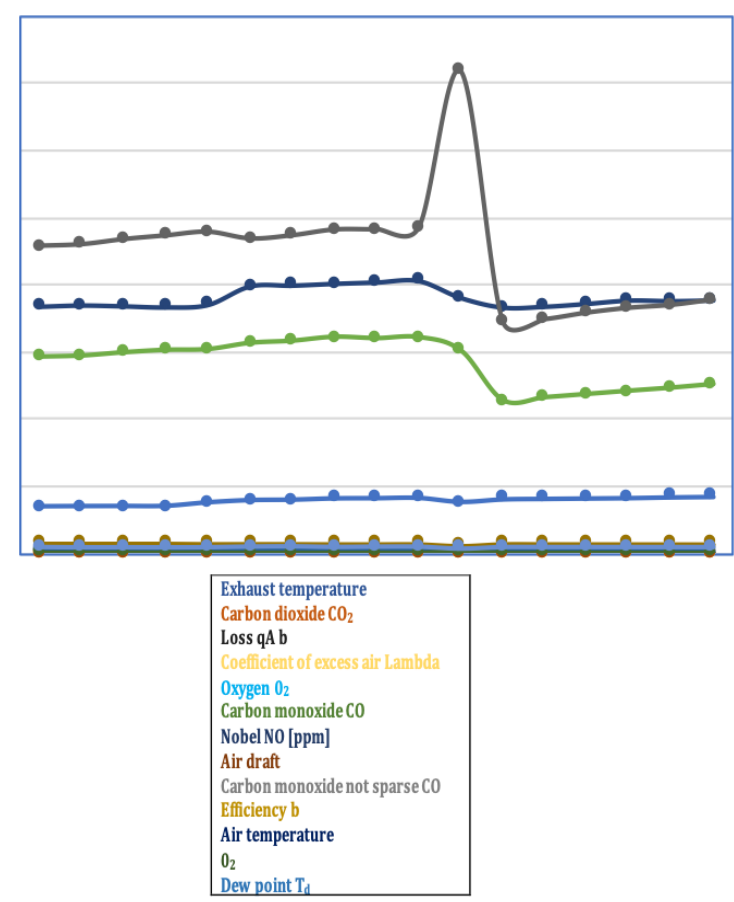

Fig. 2. Measurement values of exhaust emissions on the inland waterway vessel in real time Source: Authors' own tests. 


\section{Conclusions}

Compact exhaust gas cleaning systems, reducing nitrogen oxides and particulate matter amounts are used more and more often in the engines of non-road mobile machinery in order to comply with environmental norms. SCR-DPF technology comprises of selective catalytic reduction, which happens during the reaction of exhaust gases with ammonia using a catalyst: $4 \mathrm{NO}+4 \mathrm{NH}_{3}+\mathrm{O}_{2} \rightarrow 4 \mathrm{~N}_{2}+$ $6 \mathrm{H}_{2} \mathrm{O}$. Ammonia is formed during thermolysis and hydrolysis, after aqueous urea solution is entered into the exhaust gases. DPF (diesel particulate filter) complements this technology as is stops particulates which are later removed in a process called regeneration. When the system is installed in an inland waterway vessel, it is paramount that the system is compliant with the new technical regulations set out in Directive (EU) 2016/1629 of the European Parliament and of the Council of 14 September 2016 laying down technical requirements for inland waterway vessels, amending Directive 2009/100/EC and repealing Directive 2006/87/EC. Any vessel applying for the Union inland navigation certificate must comply with its norms and only then will be allowed to operate on international EU waterways.

\section{References}

1. Dietrich M. i inni: Podstawy konstrukcji maszyn t. I, PWN Warszawa 1986.
2. Dziama A.: Metodyka konstruowania maszyn, PWN, Warszawa, 1985.

3. Kowalski J.: Modelowanie obiektów konstrukcyjnych w projektowaniu optymalnym, WNT Warszawa 1983.

4. Osiński Z., Wróbel J.: Teoria konstrukcji maszyn, PWN Warszawa 1982.

5. Pahl G., Beitz W.: Nauka konstruowania, WNT Warszawa 1984.

6. Skarbiński M., Skarbiński J.: Technologiczność konstrukcji maszyn, WNT Warszawa 1982.

7. Tarnowski W.: Podstawy projektowania technicznego, WNT, Warszawa, 1997.

Authors:

dr inż. Wojciech Ignalewski - Faculty of Maritime Technology and Transport, West Pomeranian University of Technology in Szczecin, wojciech.ignalewski@zut.edu.pl

dr hab. inż. Magdalena Kaup - Faculty of Maritime Technology and Transport, West Pomeranian University of Technology in Szczecin, wojciech.ignalewski@zut.edu.pl

dr inż. Piotr Durajczyk - Faculty of Economics and Transport Engineering, Maritime University of Szczecin, p.durajczyk@am.szczecin.pl

mgr inż. Tomasz SKULIMOWSKI - ECOEXHAUST Sp. z 0.0., skulimowski@ecoexhaust.eu 